\title{
PHARMACOECONOMIC ASPECTS OF SCHIZOPHRENIA
}

\author{
Aleksandra Dutina1, Ivana Stašević Karličić \\ ${ }^{1}$ Clinic for psychiatric diseases "Dr. Laza Lazarević", Belgrade \\ ${ }^{2}$ Faculty of Medicine, University of Prishtina
}

ФАРМАКОЕКОНОМСКИ АСПЕКТИ СХИЗОФРЕНИЈЕ

\author{
Александра Дутина ${ }^{1}$, Ивана Сташевић Карличић ${ }^{1,2}$ \\ ${ }^{1}$ Клиника за психијатријске болести "др Лаза Лазаревић", Београд \\ 2 Медицински фракултет, Универзитет у Приштини
}

\begin{abstract}
Schizophrenia is one of the most seriouspsychiatric illnesses belonging to the group of non-affective psychoses. It is characterized by distortions of thought, perception, emotions and behavior. Twenty-four million people around the world suffer from schizophrenia. Schizophrenia is a chronic illness connected to significant expenses which are imposed on both the health system, extended social community and family, as well.Cost of illness studies of schizophrenia conducted around the world show wide range of material resources that countries set aside from their health budgets in order to cure schizophrenia. They range from $1.6 \%$ to $2.5 \%$.International cost of illness studies came to the conclusion that the costs of this disease are high, depending on the health system and location and that intangible costs per se already justify investments in research and development of new treatments.Majority of published papers suggest that atypical antipsychoticshave better cost-effectiveness profile in comparison to the first generation of antipsychotics. Olanzapine, clozapine and risperidone are atypical antipsychotics generally found to be most costeffective in treating schizophrenia.
\end{abstract}

Key words: schizophrenia, pharmacoeconomics, cost of illness

\section{САЖЕТАК}

Шизофренија је једна од најтежих психијатријских болести и спада у групу неафективних психоза. Карактерише се поремећајима мишљења, перцепције, емоција и понашања. Двадесет четири милиона људи широм света болује од шизофреније. Шизофренија је хронична болест повезана са значајним трошковима које осим здравственог система, сносе шира друштвена заједница и породица. Студије о трошковима лечења шизофреније спроведене широм света показују широк опсег средстава које земље издвајају из укупног буџета здравства за лечење шизофреније. Она се крећу од 1,6 \% до 2,5\%. Међународне студије о трошковима лечења шизофреније закључују да су трошкови ове болести високи, зависни од здравственог система и локације као и да нематеријални трошкови per se већ оправдавају улагања у испитивања и развој нових начина лечења. Већина објављених радова сугерише да атипични антипсихотици имају бољи профил трошак-ефикасност од антипсихотика прве генерације. Сматра се да оланзапин, клозапинир и сперидон имају најповољнији профил трошак-ефикасност за лечење шизофреније.

Кључне речи: шизофренија, фармакоекономија, трошкови болести. 


\section{INTRODUCTION}

Schizophrenia is one of the most serious psychiatric illnesses belonging to the group of non-affective psychoses. It is characterized by distortions of thought, perception, emotions and behavior. It is inherited poligenically. Various external factors contribute to the emergence of this disease, whilst the symptoms and the clinical manifestations are consequence of malfunctions in biochemical brain processes ${ }^{1}$. Twenty-four million people around the world suffer from schizophrenia $^{2}$. Its prevalence is estimated between 0.3 and $1 \%$ worldwide, and its incidence is from 15.2 to 20.0 per 100,000 populations/year $^{3-5}$. Schizophrenia is chronic illness associated with significant expenses which are imposed on both the health system, extended social community and family, as well ${ }^{6,7}$.

Treating schizophrenia is huge challenge for clinical doctors, due to its complex symptomatology and unpredictable, patientdependent course of illness. The illness outlook is good in $40 \%$ of cases, extremely unfavorable in $40 \%$, whereas in the remaining $20 \%$ it has moderately progressive course. The patients suffering from this illness have higher risk of comorbidity and social isolation, they have problems finding employment, while the death rate is double that of general population, which makes this illness one of the most expensive psychiatric illnesses ${ }^{8,9}$.

Discovery of the mechanism of actionfor the first antipsychotic druug 60 years ago opened a path to synthesis of new group of drugs with similar profile (antipsychotics of the first generation), which, together with psychotherapeutic and socio-therapeutic interventions were significant step forward in the treatment of schizophrenia. Thirty-five years later, many antipsychotics of the second generation have been synthesized, and turned to be as efficient as the conventional antipsychotics, but with significantly better profile of side effects and superior tolerance, offering wider range of possibilities for treating this illness ${ }^{10,11}$. Nevertheless, despite modern pharmacotherapy, $20-30 \%$ of patients have weak response to the therapy, $15-20 \%$ of the patients have relapses every year, while certain patients relapse when taking maintenance therapy ${ }^{12-14}$.

\section{SCHIZOPHRENIA AND ECONOMIC CONSEQUENCES}

Cost of illness studies of schizophrenia conducted around the world show wide range of material resources that countries set aside from their health budgets in order to treat schizophre$\mathrm{nia}^{15-18}$. They range from $1.6 \%$ to $2.5 \%{ }^{19,20}$. According to the general conclusion of the analysis of several cost of illness studies of schizophrenia given by Knapp, these costs are high, dependent on the health system and location, and intangible costs per se already justify investment in research and development of new treatments ${ }^{7}$.

Results of the costs-of-schizophrenia study conducted by Mangalor and associatesin England during 2004 and 2005, showedthat total expenses were 6.7 billion pounds, where 2 billion pounds represent direct expenses. Out of 4.7 billion pounds set aside for indirect expenses, the largest part of 3.4 billion pounds was used for expenses due to productivity loss for the reasons of sick leave, unemployment and deaths connected to schizophrenia, while the expenses of the productivity loss of caregivers amounted to 32 million pounds. The expenses of patients' families and private care were 615 million pounds. The cost of criminal proceedings with the patients suffering from schizophrenia amounted to 1 million pounds. Around 584 million pounds was set aside for the benefit payments and administration costs connected to them ${ }^{15}$.

According to the cost-of-illness study conducted in Canada during 2004, total expenses connected to schizophrenia were 6.85 billion Canadian dollars. Total direct expenses were 2.02 billion Canadian dollars. Out of 4.83 billion Canadian dollars set aside for indirect expenses, the largest part (70\% of total expenses) was spent to cover productivity loss due to morbidity. During 2004 there were 374 deaths connected to schizophrenia in Canada, which also contributed to the increase of the expenses in relation to this illness ${ }^{16}$.

According to the study of Carr and associates, Australian government set aside 1.45 billion Australian dollars during 2003 for the expenses of dealing with psychoses, including schizophrenia. The government set aside, on average, around 46,200 Australian dollars for a patient suffering from psychosis, where 27,500 Australian dollars were expenses due toproductivity loss, 13,800 Australian dollars were expenses for hospital treatment and 4,900 Australian dollars were expenses for outpatient health care ${ }^{17}$.

In USA, according to the study conducted by Cloutier and associates ${ }^{18}$, economic costs of schizophrenia equaled 155.7 billion US dollars for 2013. Direct expenses were 37.7 billion US dollars, and indirect expenses were 117.3 US billion dollars. The largest part of indirect 
expenses $(72 \%)$ was in relation to unemployment and the productivity loss of caregivers.

\section{ECONOMIC EVALUATION OF ANTIPSYCHOTICS RELATED TO THE TREATMENT OF SCHIZOPHRENIA}

Pharmacotherapy of schizophrenia is based on antipsychotic drugs. However, their effectiveness is limited, often connected with discontinuation of treatment, relapses and hospitalization $21,22,23$. Drug prescriptions appear to contribute little to total costs ${ }^{7,24,25}$, but drugs may influence hospitalization rates and productivity, thus becoming rather significant for the economics of schizophrenia $^{26,27}$.

McEvoy $^{28}$ came to a conclusion that hospitalization costs decreased in the United States of America between 1991. and 2002. However, the costs of outpatient treatment and medication went up. The decrease of inpatient costs could be explained by changes of policy and availability of new drugs for treatment of schizophrenia. In fact, there was a trend todecrease number of psychiatric beds all round the world over the last few decades,as a result of reforms in mental health care concepts and practices ${ }^{29}$. However, in spite of that, the costs of hospitalization are still the main direct cost driver of schizophrenia. Limiting length of stay and decreasing probability of relapse reduce treatment costs of schizophrenia ${ }^{3,24,25}$. Adverse effects of these drugs can vary, primarily considering higher risk of extrapyramidal syndrome concerning the firstgeneration antipsychotics (FGA) and risperidone, metabolic syndrome with olanzapine and clozapine, hyperprolactinemia with risperidone and agranulocytosis with clozapine ${ }^{26,30,31}$.

If one takes into account limited productivityof pharmacological treatment of schizophrenia, which is associated with high costs of the disease and increasingly higher expenses for medicines by health systems, it is necessary to evaluate cost-effectiveness profile of antipsychotic drugs in order to allow an adequate choice of pharmacotherapy for patients, in line with the financial reality of health systems.

Majority of published papers suggest that atypical antipsychotics have more beneficial cost-effectiveness profile in comparison to the first generation antipsychotics. According to the study conducted by Santos and associates in $2016^{32}$, which evaluated cost-effectiveness of atypical antipsychotics in Brazilian public health system, it was found that olanzapine was domi- nant over the other drugs. Nevertheless, validity of these study was not completely proven due to limited number of antipsychotic drugs included, but also due to the fact that quality of used data could not be checked.

Furthermore,randomized controlled study conducted by Davies and associates ${ }^{33}$ showed that economic costs were lower and number of quality-adjusted life years gained higher when antipsychoticsof the first generation were used in the therapy of schizophrenic populationthat was responding poorly to previous treatment, instead of atypical antipsychotics. Two more studies conducted in Great Britain came up with similar conclusions $^{34,35}$.

However, the systematic review of literature related to cost-effectiveness analysis of head-tohead comparisons of antipsychotics in schizophrenic populations that encompassed 24 studies with data from 14 countries, showed that clozapine, risperidone and olanzapine were the most cost-effective in treating schizophrenia ${ }^{36}$.

Validity of existing literature data should be carefully checked in regard to the manner of selection of subjects, method of estimation of direct and indirect treatment expenses, as well as interests of financiers. Namely, pharmaceutical companies provide studies whose results show an undoubted advantage of new medicines being placed on the market, while the research groups financed by Ministries of health or certain bureaus and funds, generally emphasize apparently cheaper and older antipsychotics ${ }^{37}$. Not only pharmacoeconomic studies, but also numerous clinical studies that analyze the problems falling within the domain of pharmacoeconomics, were the basis for modern schizophrenia treatment guidelines which give advantage to newer antipsychotics, pointing out that there are differences even among these medicines. According to the literature search, pharmacoeconomic analysis related to schizophrenia treatment as well as the cost effectiveness study of antipsychotics used in therapy still have not been conducted in Serbia.

\section{CONCLUSION}

Schizophrenia is chronic illness associated with significant expenses which are imposed on both the health system, extended social community and family, as well.International cost-of-illness studies on schizophrenia came to the conclusion that the costs are high, dependent on the health system and location and that the intangible costs per se already justify inve- 
stments in research and development of new treatments.The majority of published papers suggested that atypical antipsychoticshave more beneficial cost-effectiveness profile in comparison to the first generation drugs. Olanzapine, clozapine and risperidone are atypical antipsychotics that were generally found to be the most cost-effective in treating schizophrenia.

\section{REFERENCES}

1. Abi-Dargham A. Schizophrenia: overview and dopamine dysfunction. J Clin Psychiatry. 2014; 75(11):e31.

2. Piccinelli M, Gomez Homen F. Gender differences in the epidemiology of affective disorders and schizophrenia. Division of Mental Health and Prevention of substance abuse. Ed World Health Organization (WHO), Geneva; 1997.

3. Daltio CS, Mari JJ, Ferraz MB. Overview about pharmacoeconomics analysis and burden-of-illness in schizophrenia. Rev PsiquiatrClín. 2007; 34(2): 208-12.

4. Messias EL, Chen CY, Eaton WW. Epidemiology of schizophrenia: review of findings and myths. PsychiatrClin North Am. 2007; 30(3): 323-38.

5. McGrath J, Saha S, Chant D, Welham J. Schizophrenia: a concise overview of incidence, prevalence, and mortality. Epidemiol Rev. 2008; 30(): 67-76.

6. DegliEsposti L, Sangiorgi D, Mencacci C, Spina E, et al. Pharmaco-utilisation and related costs of drugs used to treat schizophrenia and bipolar disorder in Italy: the IBIS study. BMC Psychiatry. 2014; 14:282.

7. Knapp M, Mangalore R, Simon J. The global costs of schizophrenia. Schizophr Bull. 2004; 30(2): 279-93.

8. O'Malley AJ, Frank RG, Normand SL. Estimating cost-offsets of new medications: use of new antipsychotics and mental health costs for schizophrenia. Stat Med. 2011; 30(16): 1971-88.

9. Percudani M, Fattore G, Belloni GC, Gerzeli S, Contini A. Service utilisation and costs of first-contact patients in a community psychiatric service in Italy. Eur Psychiatry. 2002; 17(8): 434-42.

10. Lally J, MacCabe JH. Antipsychotic medication in schizophrenia: a review. British Medical Bulletin. 2015;114 (1): 169-79.

11. De Araújo AA, De AraújoDantas D, Do Nascimento GG, et al. Quality of Life in Patients with Schizophrenia: The Impact of Socio-economic Factors and Adverse Effects of Atypical Antipsychotics Drugs.Psychiatr Q. 2014; 85: 357- 67.

12. Boyer L, Millier A, Perthame E, Aballea S, Auquier P, Toumi M. Quality of life is predictive of relapse in schizophrenia.BMC Psychiatry. 2013; 13:15.

13. Ayuso-Gutiérrez JL, del Río Vega JM. Factors influencing relapse in the long-term course of schizophrenia. Schizophr Res. 1997; 28(2-3): 199-206.

14. Emsley R,Chiliza B,AsmalL, Harvey BH. The nature of relapse in schizophrenia. BMC Psychiatry. 2013; 13:50.

15. Mangalore R, Knapp M. Cost of schizophrenia in England. J Ment Health Policy Econ. 2007; 10 (1): 2341.
16. Goeree R, Farahati F, Burke N, Blackhouse G, O'Reilly D, Pyne J, Tarride JE. The economic burden of schizophrenia in Canada in 2004. Curr Med Res Opin. 2005; 21(12): 2017- 28.

17. Carr VJ, Neil AL, Halpin SA, Holmes S, Lewin TJ. Costs of schizophrenia and other psychoses in urban Australia: findings from the Low prevalence (psychotic) disorders study. Aust N Z J Psychiatry. 2003; 37(1): 31-40.

18. Cloutier M, AigbogunMS, Guerin A, Nitulescu R, Ramanakumar AV. The Economic Burden of Schizophrenia in the United States in 2013. The Journal of Clinical Psychiatry. 2016; 77(6): 764-71.

19. Cocchi A, Mapelli V, Meneghelli A, et al. Cost-effectiveness of treating first-episode psychosis: five-year follow-up results from an Italian early intervention programme. Early Interv Psychiatry. 2011; 5(3): 20311.

20. Peng X, Ascher-Svanum H, Faries D, et al. Decline in hospitalization risk and health care cost after initiation of depot antipsychotics in the treatment of schizophrenia. Clinicoecon Outcomes Res. 2011; 3: 9-14.

21. American Psychiatric Association. Diagnostic and Statistical Manual of Mental Disorders fifth edition (DSM-5). Washington: American Psychiatric Association, 2013.

22. Stroup TS, Lieberman JA, McEvoy JP, et al. Effectiveness of olanzapine, quetiapine, risperidone, and ziprasidone in patients with chronic schizophrenia following discontinuation of a previous atypical antipsychotic. Am J Psychiatry. 2006; 163(4): 611-22.

23. National Institute for Health and Care Excellence. Psychosis and schizophrenia in adults: treatment and management;

2014.https://www.nice.org.uk/guidance/cg178/evidence/full-guideline-490503565((accessed December 31, 2017).)

24. O’Day K, Rajagopalan K, Meyer K, Pikalov A, Loebel A. Long-term costeffectiveness of atypical antipsychotics in the treatment of adults with schizophrenia in the US. Clinicoecon Outcomes Res. 2013;5:459-70.

25. Jones PB, Barnes TR, Davies L, et al. Randomized controlled trial of the effect on Quality of Life of second- vs first-generation antipsychotic drugs in schizophrenia: Cost Utility of the Latest Antipsychotic Drugs in Schizophrenia. Arch Gen Psychiatry. 2006; 63(10): 1079-87.

26. Leucht S, Cipriani A, Spineli L, et al. Comparative efficacy and tolerability of 15 antipsychotic drugs in schizophrenia: a multiple-treatments meta-analysis. The Lancet. 2013; 382: 951- 62.

27. Liu-Seifert H, Ascher-Svanum H, Osuntokun O, Jen KY, Gomez JC. Change in level of productivity in the treatment of schizophrenia with olanzapine or other antipsychotics. BMC Psychiatry. 2011; 11: 87.

28. McEvoy JP. The costs of schizophrenia. J Clin Psychiatry. 2007; 68(14): 4-7.

29. Lay B, Nordt C, Rössler W. Trends in psychiatric hospitalisation of people with schizophrenia: a registerbased investigation over the last three decades. Schizophr Res. 2007; 97(1-3): 68-78.

30. Ou JJ, Xu Y, Chen HH, et al. Comparison of metabolic effects of ziprasidone versus olanzapine treatment in 
patients with firstepisode schizophrenia. Psychopharmacology (Berl). 2013; 225(3): 627-35.

31. Zhang S, Lan G. Prospective 8-week trial on the effect of olanzapine, quetiapine, and aripiprazole on blood glucose and lipids among individuals with first-onset schizophrenia. Shanghai Arch Psychiatry. 2014;26(6): 339-46.

32. Santos AS, Vidal CEL, Brandão CMR. Cost-effectiveness of atypical antipsychotics for the treatment of schizophrenia. J Bras Econ Saúde. 2016; 8(3): 204-15.

33. Davies LM, Lewis S, Jones PB, et al. Cost-effectiveness of first- v. second-generation antipsychotic drugs: results from a randomised controlled trial in schizophrenia responding poorly to previous therapy. The British Journal of Psychiatry. 2007; 191(1): 14-22.
34. Davies L, Lewis S. Antipsychotic Medication for People with Schizophrenia: An Exploratory Economic Analysis of Alternative Treatment Algorithms. 2000; Discussion Paper 178. University of York, Centre for Health Economics.

35. Bagnall AM, Jones L, Ginnelly L, et al. A systematic review of atypical antipsychotic drugs in schizophrenia.Health Technol Assess. 2003; 7(13).

36. Santos AS, GodóiIP, Vidal CEL, Ruas CM. Economic evaluation of antipsychotics for the treatment of schizophrenia: a systematic review. J Bras Econ Saúde. 2017; 9(2): 207-28.

37. Taylor D, Knapp M, Kerwin R. Pharmacoeconomics in psychiatry. London: Martin Dunitz, 2002. 